\title{
A Brief Explanation of Science Education
}

\author{
Syarofis Siayah \\ Santri Scholar Society (SSS), Kudus, Indonesia \\ siayahsyarofis26@gmail.com
}

Adib Rifqi Setiawan

$\Lambda$ lobatnio Research Society $(\Lambda \mathrm{RS})$, Kudus, Indonesia

adibrifqisetiawan@gmail.com

\begin{abstract}
This work is to explains science education that is focused exclusively on 'why' and 'how' aspect.
\end{abstract}

Keywords: learning method; science education;

\section{A. Introduction}

We have been interesting in the problem of teaching science in Indonesia, that is equal with less economically developed country, for a long time and would like to discuss it here. The problem of teaching science in Indonesia is only part of the wider problem of teaching science anywhere. In fact, it is part of the problem of teaching anything anywhere-problem for which there is no known satisfactory solution. There are many lesoon plans proposes in many countries for trying to teach science, which shows that nobody is satisfied with any methods. It is likely that many of the new lesson plans look good, for nobody has tried them long enough to find out what is the matter with them, whereas all the old methods have been with us long enough to show their faults clearly. The fact is that nobody knows very well how to tell anybody else how to teach. So when we try to figure out how to teach science we must he somewhat modest, because nobody really knows how. It is at the same time a serious problem and an opportunity for new discoveries.

The problem of teaching science in Indonesia can also be generalized in another way, to remind us of the problem of doing anything in Indonesia. We must get at least partly involved in the special social, political, and economic problems that exist here. All the problems come into sharper focus if there is before us a clear picture of the reasons for teaching science in the first place. So we will give few reasons why we believe that we should teach science. We can then ask whether any particular educational plan is in fact satisfying any of the reasons.

\section{B. Why We Should Teach Science?}

The first reason is, of course, that science's concept is a basic our activities, as such is implements to solving our environmental problem, and has all kinds of applications in technology. science is the understanding of nature, which human includes there, that tells us how things work. In particular, we are stressing here how devices of various kinds-invented by human in present and forthcoming technology_work. Therefore, those who know science will be much more useful in coping with the technical problems arising in local industry.

It might be argued - and in practice it is argued - that in the earlier stages of industrial development that we have in Indonesia especially on 1970's when Militeristic Era (1966-98), 
such talent is completely superfluous because it is so easy to import good technicallytrained personnel from more advanced countries outside. Therefore, is it really necessary to develop highly-technically-trained people locally like Tjia May On, Bacharuddin Jusuf Habibie, and Pantur Silaban?

We do not know enough economics like economist to answer correctly, but we will give an opinion anyway. We think it is vitally important to improve the technical ability of the peoples of Indonesia. By education, the man with higher technical ability is able to produce more, and we believe that in the improvement of the technical ability, and thus the productivity, of the people of Indonesia lies the source of real economic advancement. Of cource it needs long time to see that impact.

It is not economically sound to continuously import technically-skilled people. If Indonesian people were educated technically they would find positions in the developing industries here; it would soon be realized by the people who now import such workers that there is a supply of really able men and women in this country, and that this local supply has many advantages. The local people would not demand such high wages, would know the customs and ways of the country, would be glad to take more permanent positions in occational's context as well.

It is true that Indonesian with the same degrees in science or engineering as their foreign counterparts likes Singaporean seem to be very much less able. This, as we shall explain, is because they have not really been taught any science. This experience has probably conditioned industrialists to pay very little attention to the local universities. If they were wise the industrialists would see the problem quite the other way around and would be the first to clamor for a meeting of the kind we are having today, to find out what is the matter with the local product and how to teach science in a really satisfactory manner in their countries. Yet none of them are here.

A secondary reason for teaching science, or any experimental science, is that it incidentally teaches how to do things with our hands. It teaches many techniques for manipulating things as well as techniques of measurement and calculation, for example, which have very much wider applications than the particular field of study. It's also reason my agreement to Queen when they sang, "Galileo... Galileo ... Galileo figaro magnifico..." on their Bohemian Rhapsody. Galileo Galilei is an amazing figure to show how to do things with your hands, altought him's work not so applicable in our daily like Thomas Alfa Edison.

Thirdly, another major reason for teaching science is for the science itself. Science is a human activity; to many men and women it is a great pleasure and it should not be denied to the people of a large part of the world simply because of a fault or lack in the educational system. In other words, one of the reasons for teaching science is to make scientists who will not just contribute to the development of industry but also contribute to the development of understanding of nature like Isaac Newton, joining others in this great journey of our times like James Clerk Maxwell, and, of course, obtaining enormous pleasure in doing so like 'the queen for our time' Lisa Randall.

Fourthly, there is a good reason to study nature to appreciate its wonder and its beauty, even though one may not be a actively working professional scientist. This knowledge of nature also gives a feeling of stability and reality about the world and drives out many fears and 
superstitions. Was we forgot Gabrielle Émilie Le Tonnelier de Breteuil's contributed to the completion of the scientific revolution in France and to its acceptance in Europe?

A fiveth value in teaching science is to teach how things are found out. The value of questioning, the value of free ideas, not only for the development of science, but the value of free ideas in every field, becomes apparent. "Science is the belief in the ignorance of experts." said Richard Phillips Feynman at the fifteenth annual meeting of the National Science Teachers Association, 1966 in New York City. In science, at 1925, a yesterday afternoon boys at the time, Werner Karl Heisenberg, should sliding tackle a great scientist Albert Einstein to push 'the father of photoelectric effect' opinion away from the quantum field.

Science is a way to teach how something gets to be understand, what is not known, to what extent things are known, for nothing is understand absolutely, how to handle doubt and uncertainty, what the rules of evidence are, how to think about things so that judgments can be made, how to distinguish truth from fraud, show, and pseudo-science. These are certainly important secondary yields of teaching science, and science in particular.

Finally, in learning science you learn to handle trial and error, to develop a spirit of invention and of free inquiry which is of tremendous value far beyond science. One learns to ask oneself: "Is there a better way to do it?" And the answer to this is not the conditioned reflex: "Let's see how they do it in Germany, United States, and Japan," because there must certainly be a better way than that!. we don't implants social theories without understand all reasons. We must understand context when receive ideas. We must try to think of some new gimmick or idea, to find some improvement in the technique in our reality. This question is the source of a great deal of free independent thought, of invention, and of human progress of all kinds. This ends my list of reasons for the teaching of science as a science. We will continue our discussion on 'how' aspect.

\section{How to Teach Science?}

We have chosen several terms in this work that beginner will likely encounter in any exploration of science education. To provide a framework for how these terms might connect together for educator, we have used the organizing framework of scientific teaching, in which there is no prescribed or correct way to teach, rather, educators are expected to apply scientific principles to their classroom teaching efforts. Scientific teaching - also referred to as scientific approach - is an intentional approach to teaching by educators that focuses on the goal of student learning and involves iterative questioning, evidence collection, and innovation (Handelsman, et al., 2004). Scientific teaching is a pedagogical approach used in science classrooms whereby teaching and learning is approached with the same rigor as science itself.

Scientific teaching involves active learning strategies to engage students in the process of science and teaching methods that have been systematically tested and shown to reach diverse students (Handelsman, et al., 2004). The three major tenets of scientific teaching is:

a. Active learning: A process in which students are actively engaged in learning. It may include inquiry-based learning, cooperative learning, or student-centered learning.

b. Assessment: Tools for measuring progress toward and achievement of the learning goals. 
c. Diversity: The breadth of differences that make each student unique, each cohort of students unique, and each teaching experience unique. Diversity includes everything in the classroom: the students, the educators, the content, the teaching methods, and the context.

These elements should underlie educational and pedagogical decisions in the classroom. In practice, scientific teaching employs a "backward design" approach (Ebert-May \& Hodder, 2008; Wiggins \& McTighe, 1998). The educator first decides what the students should know and be able to do (learning goals), then determines what would be evidence of student achievement of the learning goals, then designs assessments to measure this achievement. Finally, the educator plans the learning activities, which should facilitate student learning through scientific discovery. There is science learning models that can support educators in translating scientific teaching into practice.

\section{Inquiry-Based Learning (Enquiry-Based Learning)}

Inquiry-based learning (enquiry-based learning in British English) is a form of active learning that starts by posing questions, problems or scenarios. Inquiry-based Learning is often assisted by a facilitator rather than a lecturer. Inquirers will identify and research issues and questions to develop knowledge or solutions. Inquiry-based learning includes problem-based learning, and is generally used in small scale investigations and projects, as well as research. The inquiry-based instruction is principally very closely related to the development and practice of thinking and problem solving skills (Dostál, 2015).

Inquiry learning involves developing questions, making observations, doing research to find out what information is already recorded, developing methods for experiments, developing instruments for data collection, collecting, analyzing, and interpreting data, outlining possible explanations and creating predictions for future study. Specific learning processes that people engage in during inquiry-learning include (Bell, et al., 2009):

a. Creating questions of their own;

b. Obtaining supporting evidence to answer the question(s);

c. Explaining the evidence collected;

d. Connecting the explanation to the knowledge obtained from the investigative process;

e. Creating an argument and justification for the explanation

There are many different explanations for inquiry teaching and learning and the various levels of inquiry that can exist within those contexts. There is clearly outlines four levels of inquiry (Banchi \& Bell, 2008):

a. Level 1: Confirmation Inquiry

The teacher has taught a particular science theme or topic. The teacher then develops questions and a procedure that guides students through an activity where the results are already known. This method is great to reinforce concepts taught and to introduce students into learning to follow procedures, collect and record data correctly and to confirm and deepen understandings.

b. Level 2: Structured Inquiry

The teacher provides the initial question and an outline of the procedure. Students are to formulate explanations of their findings through evaluating and analyzing the data that they collect.

c. Level 3: Guided Inquiry 
The teacher provides only the research question for the students. The students are responsible for designing and following their own procedures to test that question and then communicate their results and findings.

d. Level 4: Open/True Inquiry

Students formulate their own research question(s), design and follow through with a developed procedure, and communicate their findings and results. This type of inquiry is often seen in science fair contexts where students drive their own investigative questions.

Banchi and Bell (2008) explain that teachers should begin their inquiry instruction at the lower levels and work their way to open inquiry in order to effectively develop students' inquiry skills. Open inquiry activities are only successful if students are motivated by intrinsic interests and if they are equipped with the skills to conduct their own research study (Yoon, et al., 2011). An important aspect of inquiry-based learning, however, is the use of open learning, as evidence suggests that only utilizing lower level inquiry is not enough to develop critical and scientific thinking to the full potential (Zion \& Sadeh, 2010; Berg, et al., 2010; Yen \& Hunang, 2001).

Open learning has no prescribed target or result that people have to achieve. There is an emphasis on the individual manipulating information and creating meaning from a set of given materials or circumstances. Open learning has benefit that students do not simply perform experiments in a routine like fashion, but actually think about the results they collect and what they mean. In open learning there are no wrong results-even when all students is men!, and students have to evaluate the strengths and weaknesses of the results they collect themselves and decide their value.

\section{Think-Pair-Share}

The term "think-pair-share" refers to a teaching method that expects students think individually about a solution to a problem for a moment, then pair with a neighbor to share their ideas, and sometimes eventually report out to the large group (Smith, et al., 2009; Tanner, 2009). In three easy steps, every student in a class of any size can be engaged in active learning through a think-pair-share. After posing a question, the educator gives the class a few minutes to think and jot down their thoughts.

This think time is key, since different students may have different cognitive processing times because our brains all work differently. This think taime also giving students more time to just think has been shown to increase the quality of comments later shared and the number of students willing to share. Then comes the "pair" time, a few minutes for each student to say his or her ideas out loud to another student in the class.

For the vast majority of students who do not have the confidence to ask or answer questions in front of the whole class, this pair time may be the first time they have uttered a word in an undergraduate science classroom. Pair time allows students to articulate their ideas in the presence of another person; compare their ideas with those of a peer; and identify points of agreement, disagreement, and confusion. Finally comes the "share" part, in which several students are asked to share with the whole class ideas that emerged in their pair discussions.

This phase should be very familiar to most educators, since it is comparable to posing a question to an entire class. Setting up a think-pair-share activity can be as simple as posing a 
question or problem for students to think about and discuss, such as "Predict the outcome of this experiment," "Propose at least two hypotheses to explain these observations," or "Answer the multiple-choice question posted on this slide."

\section{Clickers}

Clickers are devices that can be used in classrooms of any size to ask multiple-choice questions with the goal of engaging students with the course material as part of activelearning exercises (Smith, et al., 2009; Wood, 2004). It also referred to as personal response systems. While a variety of clicker systems are available, the iClicker system has become widespread, likely because these clickers do not require integration with a particular software presentation system. While clickers can be used to check attendance, more effective uses of clickers aim to engage students in answering questions that check student understanding, challenge common misconceptions, and provide immediate conceptual feedback for both students and educators alike. While getting students to talk does not require clickers, clicker questions can be the basis of multiple think-pair-share activities during a single class period.

A key added value of using clickers is that this technological tool can give the educator an instant summary of the distribution of student responses to a multiple-choice question. This information can immediately guide an educator in deciding how to proceed, depending on the proportion of students who select the most scientifically accurate response. Clicker questions can be especially useful when asked a week or so before a section of the course is taught. Using this evidence from students, educators can identify common misconceptions held by those students, plan class activities to address these misconceptions, spend less time on those ideas that students already seem to know, and, finally, share this clicker evidence with students to explain why course time is being spent on some particular topics more than others.

\section{Minute Paper}

A minute paper is a brief active-learning strategy that provides a mechanism for students to stop, think, and write during or at the end of a class period (Allen \& Tanner, 2005; Cross \& Angelo, 1993). The goal is to provide a momentary break during which students can capture their thoughts or questions. While referred to as a "minute" paper, these brief writings can generally take one to several minutes, depending on the complexity of the question being asked. Often, questions that are most effective at challenging students' ideas and promoting rich discussions are not multiple choice, in which case clickers become less useful.

Minute papers are often driven by these non-multiple choice questions. Example minutepaper prompts might include: "What's the most useful concept or idea you learned in class today?," or "What was the muddiest point in today's class session that was most confusing for you?" or " Push yourself to write down at least two questions you have about the scientific evidence we explored in class today." Some educators require students to purchase a 100-pack of index cards as part of their course materials to facilitate frequent use of minute papers. Students are told that during each of their class meetings over the semester, they will be asked to write down their ideas on these index cards. Most of the time, educators will collect these cards, but sometimes they will not. A minute paper can serve as one way to accomplish the "think" phase of a think-pair-share, since it actively engages students in doing something to drive their thinking. 


\section{Group Work (Cooperative Learning)}

Group work, also referred to as cooperative learning, is a term that refers to activities that require students to engage in active learning with others, during which they work together toward a common outcome and practice improving their collaborative skills (Johnson, et al., 2010; Tanner, et al., 2003). Science is, by nature, a collaborative endeavor, and all scientific careers to which undergraduate students aspire will require extensive skills in working collaboratively.

To be successful, group work requires several critical elements. First, the task must be clear, with students understanding both the final goal of the activity, as well as key milestones along the way. Second, the assignment must be sufficiently complex that it necessitates collaboration. Students are clever; they know that being told to work together on a simple task is not a good use of time and will then perceive the task as busy work. As such, group sizes should reflect the complexity of the assigned task. Third, students need to know their role and the educator's expectations of them as individuals. Roles can be assigned by the educator, or in some special cases, students can be charged with self-organizing. Roles can be divided multiple ways, depending on the task. For example, roles can reflect group functions, such as facilitator, timekeeper/recorder, reporter, or equity monitor (the person who makes sure all group members' ideas are heard). Roles can also reflect authentic perspectives on a problem or issue, such as scientist, policy analyst, financial officer, business owner, or citizen/parent. Finally, group work requires the establishment of trust, grounded in a set of group norms, which are guidelines for working together that may be set by the educator or students in the course.

Examples of group norms are that everyone will contribute during discussions, ideas will be respectfully shared, and work will be fairly divided among group members. Group work and cooperative learning is often assumed to include more than two students, but usually no more than six. Importantly, the larger the size of the student group, the more care the educator must take to clearly define tasks and roles to ensure no students are left out of the group process.

\section{Peer Instruction (Peer-Led Team Learning)}

The practice of students teaching students is not new and has taken many forms over the years, as teaching an idea to someone else is often an effective way to learn. Peer instruction is defined by the act of students teaching or reviewing one another. In some peer-instruction scenarios, one student becomes an "expert" on some topic and is then tasked to teach what he or she knows to other students who are novices with respect to that material.

This approach is often used as an active-learning strategy for exploring large amounts of complex material in single class periods. For example, four research articles can be explored in a single class session in which one-quarter of the class has become expert on each paper through a prior homework assignment. During class time, student experts for each of the four papers then take turns sharing their insights and entertaining questions from peers.

Peer instruction also refers to opportunities in classrooms wherein students teach one another without there necessarily being different levels of expertise between students (Smith et al., 2009; Crouch \& Mazur, 2001; Mazur, 1997). Research has shown that two students, neither of whom was able to correctly answer a clicker question, could improve their understanding 
and correctly answer similar clicker questions after engaging in a pair discussion, which is another form of peer instruction (Smith et al., 2009).

Peer-led team learning is a particular type of peer instruction, in which students who have previously excelled in a course are invited back to serve as supplementary course discussion leaders or in-class coaches for students currently taking the course. Having most recently learned the concepts at hand, these peers-sometimes called learning assistants-may be more socially accessible to students and better able to remember the kinds of confusions students encounter with the material.

\section{Case-Based Learning and Problem-Based Learning}

Case-based and problem-based learning are teaching approaches that link course concepts to real-world scenarios and problems with which students actively engage through exploring and questioning and applying science content knowledge (Allen \& Tanner, 2003). While the goal is similar for each, the approaches vary slightly. Problem-based learning moves groups of students through a prescribed strategy of identifying what they already know and what they need to know, then determining how to access any additional information they need to solve a complex problem related to biology, such as determining mechanisms of gene inheritance or designing an experiment to distinguish between alternate hypotheses.

Case-based learning evolved from the medical and business fields; the activities task students with figuring out the underlying causes of a medical condition or a business success. Similarly, in science instruction, case-based learning begins with a situation or scenario that poses one or more issues the students need to address. Depending on the goals of the case, students may be given more or less structure in how to resolve it. Cases can range from fairly simple (one issue, one solution) to complex, real-world scenarios that scientific researchers themselves may not yet have been able to explain.

Importantly, both case-based and problem-based learning usually involve students working in structured groups in which they collaboratively identify questions and confusions and seek out additional information to expand their understanding of concepts related to the problem or case.

\section{A Glance Discussion}

As a new educator, student resistance and the potential for poor student evaluations at the end of the course can seem sufficient reason to avoid attempting active learning and becoming more innovative in the classroom. Student resistance is defined as unwillingness among one or more students to comply with educator requests (Seidel \& Tanner, 2017; Tanner, 2017). This resistance can take the form of active resistance, including complaints to department heads or vocal refusal to participate, as well as more passive forms of resistance, such as just not following educator directions and doing something else. Student resistance often seems to be rooted in students' prior experiences in classrooms and their expectations of what should be happening in an undergraduate science course. If students have experienced lecture throughout their school years, then their expectations may be unmet by this shift from their normal experiences when they enter a course with extensive active learning.

Student evaluations, defined as information gathered about the course or the teaching at some point during the semester, are a concern for most team teaching members. For example, 
students may have previously experienced poorly structured active learning or group work, resulting in generally unfavorable opinions of these teaching approaches. This is where an educator's transparency about the reasons for choosing particular teaching strategies may be critical. In addition to sharing their rationale for teaching choices, educators can also collect student evaluations throughout the course, not just at the end. This not only provides students a voice in the teaching and learning process but also gives educators insight into how students are experiencing the course midway, offering the opportunity for the educator to make adjustments.

Using the minute-paper method described earlier, educators can ask each student anonymously to share responses to: "So far, what aspects of the course are most supporting your learning?" and "So far, what aspects of the course are least supporting your learning?" Even the act of inviting student insights may go far in quelling student resistance. Finally, it may be key for educators to be quantitative in gauging the extent of student resistance and to be systematic in hearing from all students. While a few students may express resistance, the vast majority of students could deeply appreciate innovative teaching approaches, and the educator would be unaware of this without inviting midcourse student evaluation.

Educator and researcher Benjamin Bloom conceives 'bloom's taxonomy' by 1956. Bloom's taxonomy is a system with which educators can judge the nature of the assessment questions they are asking their students (Bloom et al., 1956). While many have argued about and revised the original categories of Bloom's taxonomy, the core ideas persist about how to judge the type of thinking that may be elicited by an assessment question. Bloom proposed that learning could be categorized into lower-order cognitive skills (such as knowing, remembering, or describing) and higher-order cognitive skills (such as analyzing, evaluating, inventing, or synthesizing).

Bloom's taxonomy is simple framework provides educators with a mechanism to evaluate the extent to which their student learning objectives and their assessment tools are targeting higher-order versus lower-order student thinking. Importantly, educators can often judge the nature of their assessment questions based on Bloom's taxonomy by attending to the verbs used in the assessment. Lower-order assessment questions are often those that ask students to: define, list, describe, explain, summarize, or paraphrase. In contrast, higher-order assessment questions are often those that ask students to: predict, design, apply, defend, propose, or judge. Analysis of the verbs used in either course student-learning outcomes or course assessments with reference to Bloom's taxonomy can be a useful exercise for educators who are re-evaluating their approach to teaching.

Science educators focus a great deal of time and energy on issues of "what" students should be learning, as well as on the "how" of teaching. Yet the aspect of classroom teaching that seems to be consistently underappreciated is the nature of "whom" we are teaching. Undergraduate students often appear to be treated as monolithic without attention to research on the pervasive influence that an individual's personal history and characteristics, culture, and prior experiences in society and in classrooms all have on the teaching and learning processes in our own classrooms. So I recommends in science education, the most important aspect is understanding, communicating about, and gaining insight into "whom" we are teaching and the efforts underway across the nation to make science teaching and learning more fair. It is why I use different models, even when I teach same content for guide students to one goal: achieving scientific literacy. 


\section{E. Conclusion}

We are moslem, an asy'arits moslem, that believe in six axioms or postulates called arkān alimān (Arabic: أركان الإيمان). So, as an analogues to our faith, we will say that the six reason is arkān ta'lìm al-ulūm al- tobi'îyyat (Arabic: تعليم العلوم الطبيعية) or basic principles to teaching science, these are:

1. science's concept is a basic our activities that implements to solving our environment problem, and has all kinds of applications in technology.

2. Teaching science is incidentally teaches how to do things with your hands.

3. To make scientists who will not just contribute to the development of industry but also contribute to the development of understanding of nature (which human includes there), joining others in this great journey of our times, and obtaining enormous pleasure in doing so.

4. To study nature to appreciate its wonder and its beauty, that will gives a feeling of stability and reality about the world and drives out many fears and superstitions.

5. Teach how things are found out, to belief in the ignorance of experts.

6. Learn to handle trial and error, to develop a spirit of invention and of free inquiry which is of tremendous value far beyond science.

Based on this highlights, it seem that the first cornerstone of scientific teaching is active learning. All science educators has traditionally focused much of our conversation about teaching and learning on issues of "what" exactly students should be learning, however, attention is increasingly being paid to the "how" of teaching. Multiple lines of research efforts in a variety of disciplines have provided evidence that traditional lecture approaches to teaching are much less effective than teaching approaches that actively engage students in the learning process (Freeman, et al., 2014; Bransford, et al., 2000; Handelsman et al., 2004). Active-learning approaches to teaching encompass a range of strategies-from simple to complex, from activities that last just a few minutes to longer projects, from inside class time to outside class time. Common to all these active-learning strategies is the acknowledgment that learning is a phenomenon of the human brain, and the individuals doing the learning must be actively involved in constructing meaning, examining their prior ideas, and resolving conceptual confusions, just as scientists do in their own efforts to learn how the natural world works. Finally, the most important aspect is understanding, communicating about, and gaining insight into "whom" we are teaching and the efforts underway across the nation to make science teaching and learning more fair.

This essay don't give descriptions of some of the major characteristics of science education in Indonesia which appear to me to be of special concern for us. Finally, sciences do not directly teach good and bad, love do. I don't trying to fill my head with sciences, for to fill my heart with love is enough. So, sciences is not the most important thing, love is. I don't believe I can really do anything without loving something. So, "How can I make students love science?" or in general, "How can someone can falling in love?" I leave you all with this question.

\section{References}

Allen, Deborah E., \& Tanner, Kimberly D. (2003, Spring). Learning in context: problembased learning. Cell Biology Education, 2: 73-81. DOI: https://dx.doi.org/10.1187\%2Fcbe.03-04-0019

Allen, Deborah E., \& Tanner, Kimberly D. (2005, Winter). Infusing active learning into the large enrollment biology class: seven strategies, from the simple to complex. Cell 
Biology Education, 4(4): 262-268. DOI: https://dx.doi.org/10.1187\%2Fcbe.05-080113

Banchi, Heather, \& Bell, Randy. (2008, October). The many levels of inquiry. Journal of Science and. Children, 15(4): 516-529. URL:

https://www.questia.com/library/journal/1G1-187423616/the-many-levels-of-inquiryinquiry-comes-in-various

Bell, Thorsten, et al. (2009, 02 June). Collaborative inquiry learning: models, tools, and challenges. International Journal of Science Education, 3 (1): 349-377. DOI: https://dx.doi.org/10.1080\%2F09500690802582241

Berg, C. Anders R., et al. (2010, 26 November). Benefiting from an open-ended experiment? A comparison of attitudes to, and outcomes of, an expository versus an open-inquiry version to the same experiment. International Journal of Science Education, 25 (3): 351-372. DOI: https://dx.doi.org/10.1080/09500690210145738

Bloom, Benjamin S, et al. (1956). A taxonomy of educational objectives, handbook 1: cognitive domain. McKay. URL:

https://www.uky.edu/ rsand1/china2018/texts/Bloom\%20et\%20a1\%20Taxonomy\%20of\%20Educational\%20Objectives.pdf

Bransford, John D., et al. (2000). How people learn: brain, mind, experience, and school. National Academies Press. URL: https://www.desu.edu/sites/flagship/files/document/16/how_people_learn_book.pdf

Cross, Patricia K., \& Angelo, Thomas A. (1988). Classroom assessment techniques: a handbook for college teachers. The National Center for Research to Improve Postsecondary Teaching and Learning. URL: https://files.eric.ed.gov/fulltext/ED317097.pdf

Crouch, Catherine H., \& Mazur, Eric. (2001, March). Peer instruction: ten years of experience and results. American Journal of Physics, 69: 970-977. DOI: https://dx.doi.org/10.1119/1.1374249

Dostál, Jiří. (2015). Inquiry-based instruction : concept, essence, importance and contribution. Palacký University. DOI: https://dx.doi.org/10.5507/pdf.15.24445076

Ebert-May, Diane, \& Hodder, Janet. (2008). Pathways to scientific teaching. W. H. Freeman.

Freeman, Scott, et al. (2014, 12 May). Active learning increases student performance in science, engineering, and mathematics. Proceedings of the National Academy of Sciences of the United States of America, 111(23), 8410-8415. DOI: https://dx.doi.org/10.1073/pnas.1319030111

Handelsman, Jo, et al. (2004, 23 April). Scientific teaching. Science 304, 521-522. URL: http://scientificteaching.wisc.edu/documents/ScientificTeaching.pdf

Johnson, David W, et al. (2010, 25 March). Cooperative learning returns to college: what evidence is there that it works? Change, 4: 26-37. DOI: https://dx.doi.org/10.1080/00091389809602629

Mazur, Eric. (1997). Peer Instruction: A User's Manual. Prentice-Hall. URL: https://issuu.com/alobatnic/docs/preview_peer_instruction_a_user__s

Seidel Shannon B., \& Tanner Kimberly D. (2017, 13 October). What if students revolt?considering student resistance: origins, options, and opportunities for investigation. CBE-Life Sciences Education, 12(4): 586-595. DOI: https://dx.doi.org/10.1187/cbe13-09-0190

Smith, M.K., et al. (2009, 02 January). Why peer discussion improves student performance on in-class concept questions. Science, 323: 122-124. DOI: https://dx.doi.org/10.1126/science.1165919 
Tanner, Kimberly D. (2009, Spring). Talking to learn: why biology students should be talking in classrooms and how to make it happen. CBE-Life Sciences Education, 8: 89-94. DOI: https://dx.doi.org/10.1187\%2Fcbe.09-03-0021

Tanner, Kimberly D. (2017, 13 October). Moving theory into practice: a reflection on teaching a large introductory biology course for majors. CBE_Life Sciences Education, 10(2): 113-122. DOI: https://dx.doi.org/10.1187/cbe.11-03-0029

Tanner, Kimberly, et al. (2003, Spring). Cooperative learning in the science classroom: beyond students working in groups. Cell Biology Education, 2: 1-5. DOI: https://dx.doi.org/10.1187\%2Fcbe.03-03-0010

Wiggins, Grant, \& McTighe, Jay. (1998). Understanding by design. Association for Supervision and Curriculum Development.

Wood, William B. (2004). Clickers: a teaching gimmick that works. Developmental Cell, 7(6): 796-798. DOI: http://dx.doi.org/10.1016/j.devcel.2004.11.004

Yen, Chiung-Fen, \& Hunang, Shin-Chieh. (2001). Authentic learning about tree frogs by preservice biology teachers in an open-inquiry research settings. Proceedings of the National Science Council Republic of China (D), 11: 1-10. URL: https://ejournal.stpi.narl.org.tw/index/items/download?viId=3889B502-8692-48C1A979-E28C893C9E80

Yoon, Hye-Gyoung, et al. (2011, 22 March). The challenges of science inquiry teaching for pre-service teachers in elementary classrooms: difficulties on and under the scene. Research in Science \& Technological Education, 42(3): 589-608. DOI: https://dx.doi.org/10.1007/s11165-011-9212-y

Zion, M.ichal, \& Sadeh, Irit. (2010, 13 December). Curiosity and open inquiry learning. Journal of Biological Education, 41 (4): 162-168. DOI: https://dx.doi.org/10.1080\%2F00219266.2007.9656092 